\title{
ОСОБЛИВОСТІ РЕМОДЕЛЮВАННЯ ПІДСЛИЗОВИХ ЗАЛОЗ ДВАНАДЦЯТИПАЛОЇ КИШКИ В УМОВАХ ПОСТРЕЗЕКЦІЙНОї ПОРТАЛЬНОЇ ГІПЕРТЕНЗІЇ
}

\begin{abstract}
Резюме. Відомо, що видалення великих об'ємів печінки призводить до пострезекційної портальної гіпертензії, яка ускладнюється кровотечами з варикозно розширених вен стравоходу, шлунка, прямої кишки, асцитом, спленомегалією, вторинним гіперспленізмом, паренхіматозною жовтяницею та портосистемною енцефалопатією. Пострезекційна портальна гіпертензія призводить до структурної перебудови органів басейну ворітної печінкової вени, а також ремоделювання їх структур. Гемодинамічні розлади при гіпертензії у системі ворітної печінкової вени ускладнюються вираженими морфологічними змінами в оболонках дванадцятипалої кишки, при яких особливості ремоделювання її підслизових залоз вивчено недостатньо.

Мета дослідження - вивчити особливості ремоделювання підслизових залоз дванадцятипалої кишки в умовах пострезекційної портальної гіпертензії.

Матеріали і методи. Дослідження проведено на 45 лабораторних статевозрілих білих щурах-самцях, яких поділили на 3 групи: перша група нараховувала 15 інтактних практично здорових тварин, друга - 15 щурів після резекції лівої бокової частки - 31,5 \% паренхіми печінки, третя -15 щурів після видалення правої та лівої бокових часток печінки (58,1 \%). Евтаназію дослідних тварин здійснювали кровопусканням в умовах тіопентал-натрієвого наркозу через місяць від початку досліду. Із дванадцятипалої кишки виготовляли гістологічні мікропрепарати. Морфометрично визначали діаметр підслизових залоз дванадцятипалої кишки, висоту мукоцитів підслизових залоз, діаметр їх ядер, ядерно-цитоплазматичні відношення в мукоцитах та відносний об'єм ушкоджених мукоцитів. Кількісні показники обробляли статистично.

Результати досліджень та їх обговорення. Результати аналізу отриманих даних встановили, що через місяць після резекції 31,5 \% паренхіми печінки більшість структур підслизових залоз дванадцятипалої кишки не змінювалася. Відносний об'єм ушкоджених мукоцитів підслизових залоз дванадцятипалої кишки при цьому статистично достовірно (p<0,001) зріс у 1,5 раза. У дослідних тварин при видаленні 58,1 \% паренхіми печінки при розтині очеревинної порожнини спостерігали розширення печінкової ворітної вени, повнокров'я і розширення брижових вен та видимого венозного русла тонкої та товстої кишок, асцит, спленомегалію, що підтверджувало наявність пострезекційної портальної гіпертензії. Через місяць після резекції 58,1 \% паренхіми печінки досліджувані морфометричні параметри суттєво змінювалися. Так, діаметр підслизових залоз дванадцятипалої кишки статистично достовірно (р<0,001) зріс на 25,9\%. Висота мукоцитів підслизових залоз дванадцятипалої кишки у даних експериментальних умовах із високим ступенем статистично достовірної різниці $(p<0,001)$ зменшилася на $12,1 \%$, порівняно з аналогічним контрольним кількісним морфологічним показником, а діаметр їх ядер - на 7,3 \%. Нерівномірні диспропорційні зміни просторових характеристик ядра та цитоплазми мукоцитів призводили до виражених порушень ядерноцитоплазматичних відношень у цих клітинах. При цьому вказаний морфометричний параметр статистично достовірно (р<0,01) збільшився на 11,1%. Виявлені зміни ядерно-цитоплазматичних відношень свідчили про порушення структурного клітинного гомеостазу. Відносний об'єм ушкоджених мукоцитів підслизових залоз дванадцятипалої кишки через місяць після видалення $58,1 \%$ паренхіми печінки з вираженою статистично достовірною різницею $(p<0,001)$ зріс у 9,7 раза.

Висновки. Резекція великих об'ємів паренхіми печінки призводить до пострезекційної портальної гіпертензії та вираженої структурної перебудови підслизових залоз дванадцятипалої кишки, яке підтверджується змінами їх топографії, порушенням клітинного структурного гомеостазу мукоцитів та вираженим зростанням відносного об'єму їх ушкоджень, інфільтративними та склеротичними процесами, що істотно погіршує функціональну морфологію залоз та посилює дисфрункцію досліджуваного органа.
\end{abstract}

Ключові слова: резекція печінки; підслизові залози дванадцятипалої кишки; мукоцити; морфометрія.

ВСтУп Сьогодні резекцію печінки нерідко виконують у хірургічних стаціонарах. Показаннями до даної операції є доброякісні та злоякісні пухлини, метастази, травми печінки, внутрішньопечінковий холангіолітіаз, альвеолярний ехінококоз, трансплантація печінки $[2,9,10]$. Резекція великих об'ємів печінки може призводити до різних пострезекційних ускладнень: кровотечі з варикозно розширених вен стравоходу, шлунка, прямої кишки, асциту, спленомегалії, вторинного гіперспленізму, паренхіматозної жовтяниці, портосистемної енцефалопатії, печінкової недостатності, гепаторенального синдрому, поліорганної недостатності, портальної гіпертензії [2, 3, 9]. Пострезекційна портальна гіпертензія призводить до морфологічної перебудови органів басейну ворітної печінкової вени, а також ремоделювання їх структур. Дванадцятипала кишка належить до органів, венозний дренаж від яких здійснюють через ворітню печінкову вену, де гемодинамічні розлади ускладнюються різними морфологічними змінами у судинах та структурах вказаного органа. Відомо, що у дванадцятипалій кишці в підслизовому прошарку локалізовані підслизові залози, які називають дуоденальними залозами, або залозами Бруннера, що продукують слизовий секрет (муцин), який відіграє важливу роль у захисті слизової оболонки. Варто зазначити, що фрункціональну морфологію підслизових залоз дванадцятипалої кишки при пострезекційній портальній гіпертензії вивчено недостатньо.

Метою дослідження було вивчити особливості ремоделювання підслизових залоз дванадцятипалої кишки в умовах пострезекційної портальної гіпертензії.

МАТЕРІАЛИ I МЕТОДИ Дослідження проведені на 45 лабораторних статевозрілих білих щурах-самцях, яких поділили на 3 групи: перша група нараховувала 15 інтактних практично здорових тварин, друга - 15 щурів після резекції лівої бокової частки - 31,5 \% паренхіми печінки, 3-я - 15 тварин після видалення правої та лівої бокових часток печінки (58,1%) [3]. Через місяць від початку експерименту виконували евтаназію дослідних тварин кровопусканням в умовах тіопентал-натрієвого наркозу. Вирізані шматочки із дванадцятипалої кишки фріксували в $10 \%$ нейтральному розчині формаліну і після відповідного проведення через етилові спирти зростаючої концентрації заливали у парафрінові блоки за загальноприйнятою методикою. Гістологічні зрізи товщиною 5-7 мкм після депарафрінізації фрарбували гематоксилін-еозином, за 
Ван-Гізон, Маллорі, Вейгертом, толуїдиновим синім [8]. Усі маніпуляції та евтаназію щурів проводили з дотриманням основних принципів роботи з експериментальними тваринами відповідно до положень Європейської конвенції про захист хребетних тварин, що використовуються для дослідних та інших наукових цілей (Страсбург, 1986), Загальних етичних принципів експериментів на тваринах, ухвалених Першим національним конгресом 3 біоетики (Київ, 2001), а також Закону України Про захист тварин від жорстокого поводження (від 21.02.2006) [4].

Проводили морфометрію, при якій визначали діаметр залоз (ДЗ), висоту мукоцитів підслизових залоз дванадцятипалої кишки (ВМ), діаметр їх ядер (ДяМ), ядерноцитоплазматичні відношення в мукоцитах (ЯЦВМ) та відносний об'єм ушкоджених мукоцитів підслизових залоз дванадцятипалої кишки (ВОУМ) [1, 3]. Кількісні показники обробляли статистично. Обробку результатів виконано у відділі системних статистичних досліджень ДВНЗ “Тернопільського державного медичного університету імені I. Я. Горбачевського МОЗ України" в програмному пакеті STATISTIKA. Різницю між порівнювальними величинами визначали за критерієм Стьюдента та Манна-Уїтні [5].

РЕЗУЛЬТАТИ ДОСЛІДЖЕНЬ ТА ЇХ ОБГОВОРЕННЯ Кількісні морфологічні показники, отримані в результаті проведеного дослідження, що характеризували підслизові залози дванадцятипалої кишки, показані у таблиці. Аналіз отриманих даних встановив, що через місяць після резекції 31,5 \% паренхіми печінки більшість 3 них не змінювалася. У даних експериментальних умовах тільки відносний об'єм ушкоджених мукоцитів підслизових залоз дванадцятипалої кишки статистично достовірно $(p<0,001)$ зріс із $(2,30 \pm 0,03) \%$ до $(3,45 \pm 0,04) \%$, тобто у 1,5 раза. Виявлене зростання вказаних структур можна пояснити посиленням їх апоптозу, що має місце при стресах, яким є проведена операція [3, 9].

У дослідних тварин при видаленні 58,1 \% паренхіми печінки при розтині очеревинної порожнини спостерігали розширення печінкової ворітної вени, повнокров'я і розширення брижових вен та видимого венозного русла тонкої та товстої кишок, асцит, спленомегалію. У дванадцятипалій кишці виявлялися виражені судинні розлади, які характеризувалися повнокров'ям переважно венозних судин. У венозній ланці гемомікроциркуляторного русла було розширення мікросудин, повнокров'я, стази, тромбози, осередки діапедезних крововиливів. Вищеописані зміни у басейні печінкової ворітної вени та венозному руслі дванадцятипалої кишки підтверджують наявність пострезекційної портальної гіпертензії, яка виникла після видалення 58,1 \% паренхіми печінки [6].

Через місяць після резекції 58,1 \% паренхіми печінки досліджувані морфометричні параметри суттєво змінювалися. Так, діаметр підслизових залоз дванадцятипалої кишки зріс з $(27,4 \pm 0,3)$ мкм до $(34,5 \pm 0,6)$ мкм. Між наведеними морсоометричними параметрами встановлено статистистично достовірну різницю ( $<<0,001)$. При цьому останній морфометричний параметр перевищував попередній на 25,9\%.

Висота мукоцитів підслизових залоз дванадцятипалої кишки у даних експериментальних умовах із високим ступенем достовірну різницю ( $<<0,001)$ зменшилася на $12,1 \%$, порівняно з аналогічним контрольним кількісним морорологічним показником, а діаметр їх ядер - на 7,3 \%. Нерівномірні диспропорційні зміни просторових характеристик ядра та цитоплазми мукоцитів призводили до виражених порушень ядерно-цитоплазматичних відношень у цих клітинах. При цьому вказаний морфометричний параметр статистично достовірно ( $<<0,01)$ збільшився на 11,1 \%. Виявлені зміни ядерно-цитоплазматичних відношень свідчили про порушення структурного клітинного гомеостазу $[1,7]$. Відносний об'єм ушкоджених мукоцитів підслизових залоз дванадцятипалої кишки через місяць після видалення 58,1 \% паренхіми печінки з вираженою статистично достовірною різницею ( $<<0,001)$ зріс у 9,7 раза.

Гістологічно в оболонках стінки дванадцятипалої кишки спостерігалися виражені судинні розлади, набряки строми, осередки дистрофрічно, некробіотично, апоптично змінених епітеліоцитів, мукоцитів підслизових залоз дванадцятипалої кишки, гладких міоцитів м'язової оболонки, ендотеліоцитів судин, стромальних структур, вогнищеві клітинні інфільтрати та розростання строми. Відмічали набряк епітеліоцитів слизової оболонки, мукоцитів підслизових залоз дванадцятипалої кишки, їх дистрофрію, некробіоз, десквамацію. Проліферація ендотеліоцитів у судинах дванадцятипалої кишки підтверджувала наявність гіпоксії. Виявлялося просякання мембран ендотеліоцитів, судинної стінки білками плазми. У деяких досліджуваних судинах спостерігали осередки фрібриноїдного набряку та некрозу, що свідчило про виражене їх ушкодження. Підслизові залози дванадцятипалої кишки за будовою $є$ трубчасто-альвеолярними, розміщуючись переважно у підслизовому прошарку. Їх вивідні протоки проникають через власну пластинку слизової оболонки і відкриваються на дні кишкових крипт. Гладкі міоцити слизової оболонки виконують функцію замикаючих апаратів для вивідних проток залоз, регулюючи потрапляння секрету в просвіт кишки, що залежить також від її моторики. Секреторні відділи підслизових залоз дванадцятипалої кишки оточені каркасом переважно із еластичних волокон, зв'язаних із гладкими міоцитами, які при скороченні забезпечують активне виведення секрету.

В умовах пострезекційної портальної гіпертензії збільшення діаметра залоз, переповнення їх секретом свідчило про порушення його виведення. Нерідко в умовах змодельованого експерименту секреторні відділи даних

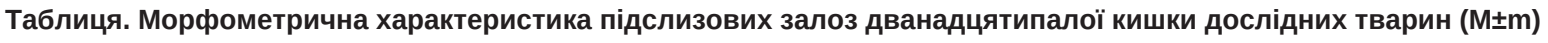

\begin{tabular}{|l|c|c|c|}
\hline \multirow{2}{*}{ Показник } & \multicolumn{2}{|c|}{ Група спостереження } \\
\cline { 2 - 4 } & перша & друга & третя \\
\hline ДЗ (мКм) & $27,4 \pm 0,3$ & $27,9 \pm 0,6$ & $6,12 \pm 0,6^{\star \star \star}$ \\
\hline ВМ (мКМ) & $6,96 \pm 0,06$ & $6,94 \pm 0,06$ & $3,06 \pm 0,02^{\star \star}$ \\
\hline ДЯМ (мКм) & $3,30 \pm 0,03$ & $3,30 \pm 0,04$ & $0,236 \pm 0,004^{\star}$ \\
\hline ЯЦВМ & $0,225 \pm 0,002$ & $0,226 \pm 0,003$ & $22,4 \pm 0,3^{\star \star \star}$ \\
\hline ВОПМ (\%) & $2,30 \pm 0,03$ & $3,45 \pm 0,04^{\star \star \star}$ & \\
\hline
\end{tabular}

Примітка. * $-p<0,05 ;$ ** $-p<0,01 ; * \star \star ~-~ p<0,001$ порівняно з першою групою. 
залоз локалізувалися не тільки у підслизовому прошарку, але і в товщі слизової оболонки дванадцятипалої кишки, безпосередньо біля дна кишкових крипт, тобто змінювалася їх топографія. Збільшення кількості лімфоїдних клітин навколо ацинарних відділів залоз, які безпосередньо локалізовані до їх сполучнотканинного каркасу, можуть руйнувати його еластичні волокна. Останнє, а також розростання сполучної тканини, мали місце через місяць після резекції 58,1 \% паренхіми печінки. Дистрофрія, некробіоз, десквамація, атрофрія мукоцитів, зміна топографії залоз, розростання сполучної тканини можуть сприяти застою секрету і призводити до утворення мікрокист. В цих умовах проходить активація власних протеолітичних ферментів, а при недостатності замикаючих апаратів вивідних проток залоз здійснюється ресрюкс неактивованих ферментів, які потрапляють у дванадцятипалу кишку, що створює умови для аутолізу підслизових залоз дванадцятипалої кишки та утворення глибоких дефектів у слизовій оболонці.

Отримані дані дозволяють стверджувати, що існує тісна залежність між морфологічними змінами у слизовій оболонці дванадцятипалої кишки та порушенням структури підслизових залоз даного органа. Значні резекції паренхіми печінки призводять до пострезекційної портальної гіпертензії, виражених уражень структур слизової оболонки дванадцятипалої кишки та її підслизових залоз, що посилює диссункцію досліджуваного органа.

ВИСНОВКИ Резекція великих об'ємів паренхіми печінки призводить до пострезекційної портальної гіпертензії та вираженої структурної перебудови підслизових залоз дванадцятипалої кишки, яке підтверджується змінами їх топограсрії, порушенням клітинного структурного гомеостазу мукоцитів та вираженим зростанням відносного об'єму їх ушкоджень, інорільтративними та склеротичними процесами, що істотно погіршує фрункціональну морфологію залоз та посилює диссрункцію досліджуваного органа.

Перспективи подальших досліджень Всебічне, адекватне вивчення підслизових залоз дванадцятипало кишки в умовах пострезекційної портальної гіпертензії дозволить суттєво розширити діагностику, корекцію та профрілактику досліджуваної патології.

\section{СПИСОК ЛІТЕРАТУРИ}

1. Автандилов Г. Г. Основы количественной патологической анатомии / Г. Г. Автандилов. - М. : Медицина, 2002. - 240 с.

2. Вишневский В. А. Сегментарные резекции, отдаленные результаты при злокачественных опухолях печени / В. А. Вишневский, М. Г. Ефанов, И. В. Казаков // Укр. журнал хірургії. 2012. - № 1 (16). - C. 5-15.

3. Гнатюк М. С. Морфометрична оцінка особливостей ремоделювання структур дванадцятипалої кишки при резекції різних об'ємів печінки / М. С. Гнатюк, Л. В. Татарчук, О. Б. Ясіновський // Науковий вісник Ужгородського університету. Серія "Медицина". - 2016. - Вип. 1 (53). - С. 92-95.

4. Загальні етичні принципи експериментів на тваринах // Ендокринологія. - 2003. - Т. 8, № 1. - С. 142-145.

5. Лапач С. Н. Статистические методы в медико-биологических исследованиях Excell / С. Н. Лапач, А. В. Губенко, П. Н. Бабич. - К. : Морион, 2001. - 410 c.

6. Пилипко І. В. Синдром портальної гіпертензії та механізми його розвитку при печінковій патології / І.В.Пилипко // Вісник наукових досліджень. - 2015. - № 4. - С. 7-10.

7. Саркисов Д. С. Структурне основы адаптации и компенсации нарушенных фрункций / Д. С. Саркисов. - М. : Медицина, 1998. - 230 c.

8. Сорочинников А. Г. Гистологическая и микроскопическая техника / А. Г. Сорочинников, А. Е. Доросевич. - М. : Медицина. $-2007 .-448$ c.

9. Основные осложнения обширных резекций печени и пути их предупреждения / В. Д. Федоров, В.А.Вишневский, Н. А. Назаренко [и др.] // Бюлл. сибирской медицины. - 2007. № 4. - C. 16-24.

10. Reddy S. S. From child-pugh to model for end-stage liver disease: deciding who needs a liver transplant / S. S. Reddy, J. M. Civan // Med. Clin. Noth. Am. -2016. - Vol. 100, No. 3. -P. 449-464.

Отримано 03.10.18

Електронна адреса для листування: Tatarchyklv@tdmu.edu.ua

\section{REMODELING PECULIARITIES OF DUODENAL SUBMUCOSAL GLANDS IN CONDITIONS AT POSTRESECTION PORTAL HYPERTENSION}

Summary. It is known that the removal of large volumes of the liver leads to postresection portal hypertension, which is complicated by bleeding from varicose veins of the esophagus, stomach, rectum, ascites, splenomegaly, secondary hypersplenism, parenchymal jaundice and portosystemic encephalopathy. Postresection portal hypertension leads to structural rearrangement of the organs of the basilar portal hepatic vein, as well as the remodeling of their structures. Hemodynamic disorders with hypertension in the portal hepatic vein are complicated by pronounced morphological changes in the duodenum, under which the features of remodeling of its submucosal glands are insufficiently studied.

The aim of the study - to learn the features of remodeling of submucosal glands of the duodenum in conditions of postresection portal hypertension.

Materials and Methods. The research was conducted on 45 laboratory-sexually mature white male rats, which were divided into 3 groups. The group 1 consisted of 15 intact virtually healthy animals, 2-15 rats after resection of the left lateral part - 31.5 \% of liver parenchyma, 3-15 animals after removal of the right and left lateral parts of the liver (58.1\%). Euthanasia of experimental animals was carried out by bloodletting in conditions of thiopental anesthesia 1 month after the beginning of the experiment. From the duodenum, histological micropreparations were made. Morphometrically the diameter of the submucosal glands of the duodenum was determined, 
the height of the mucocytes cells of the submucous glands, the diameter of their nuclei, the nuclear-cytoplasmic ratio in the mucocytes, and the relative volume of the damaged mucocytes. Quantitative indicators were processed statistically.

Results and Discussion. The analysis of the data obtained found that, after a month after resection of $31.5 \%$ of the liver parenchyma, most of the structures of the duodenal submucosal glands did not change. The relative volume of damaged mucocytes of the submucous glands of the duodenum with a statistically significant increase $(p<0.001)$ by 1.5 times. In experimental animals, in the removal of $58.1 \%$ of liver parenchyma at the intersection of the peritoneal cavity, there was an enlargement of the hepatic portal vein, enlargement of the erythematous mesenterium veins and the visible veins of the small and large intestines, ascites, splenomegaly, which confirmed the presence of postresection portal hypertension. One month after resection of $58.1 \%$ of liver parenchyma, the morphometric parameters studied significantly changed. Thus, the diameter of the submucosal glands of the duodenum statistically significantly $(p<0.001)$ increased by $25.9 \%$. The height of the mucocytes of the duodenal submucosal glands in the experimental conditions with a high degree of significant difference $(p<0.001)$ decreased by $12.1 \%$ compared with the similar control quantitative morphological index, and the diameter of their nuclei - by $7.3 \%$. Nonuniform disproportionate changes in spatial characteristics of the nucleus and cytoplasm of mucocytes resulted in marked violations of nuclear-cytoplasmic relations in these cells. In this case, the indicated morphometric parameter is statistically significant $(p<0.01)$ increased by $11.1 \%$. The detected changes in the nuclear-cytoplasmic relationships showed an alteration in structural cellular homeostasis. The relative volume of damaged mucocytes of the duodenal submucosal glands one month after the removal of $58.1 \%$ of liver parenchyma with a pronounced statistically significant difference $(p<0.001)$ increased by 9.7 times.

Conclusions. Resection of large volumes of liver parenchyma leads to postresection portal hypertension and severe structural rearrangement of the duodenal submucosal glands, which is confirmed by changes in their topography, a violation of cellular structural homeostasis of mucocytes and a marked increase in the relative volume of their damage, infiltrative and sclerotic processes, which significantly impairs functional morphology of glands and increases the dysfunction of the investigated organ.

Key words: liver resection; duodenal submucosal gland; mucous cell; morphometry.

(СА. Г. Шульгай, Л. В. Татарчук, М. С. Гнатюк

ГВУз “Тернопольский государственный медицинский университет имени И. Я. Горбачевского”

\section{ОСОБЕННОСТИ РЕМОДЕЛИРОВАНИЯ ПОДСЛИЗИСТЫХ ЖЕЛЕЗ ДВЕНАДЦИТИПЕРСТНОЙ КИШКИ В УСЛОВИЯХ ПОСТРЕЗЕКЦИОННОЙ ПОРТАЛЬНОЙ ГИПЕРТЕНЗИИ}

Резюме. Известно, что удаление больших объемов печени приводит к пострезекционной портальной гипертензии, что осложняется кровотечением с варикозно расширенных вен пищевода, желудка, прямой кишки, асцитом, спленомегалией, вторичным гиперспленизмом, паренхиматозной желтухой и портосистемной энцефалопатией. Пострезекционная портальная гипертензия приводит к структурной перестройке органов басейна воротной печеночной вены, а также ремоделированию их структур. Гемодинамические расстройства у системе воротной печеночной вены осложняются выраженными морфологическими изменениями у оболочках двенадцатиперстной кишки, при которых особенности ремоделирования ее подслизистых желез изучены недостаточно.

Цель исследования - изучить особенности ремоделирования подслизистых желез двенадцатиперстной кишки в условиях пострезекционной портальной гипертензии.

Материалы и методы. Исследования проведены на 45 лабораторных половозрелых белых крысах-самцах, которые были разделены на 3 группы: первая группа включала 15 интактных практически здоровых животных, вторая - 15 крыс после резекции левой боковой доли - 31,5 \% паренхимы печени, третья -15 животных после удаления правой и левой боковых долей печени $(58,1$ \%). Эвтаназия животных осуществлялась кровопусканием в условиях тиопентал-натриевого наркоза через месяц от начала эксперимента. С двенадцатиперстной кишки изготовляли гистологические микропрепараты. Морфометрически определяли диаметр подслизистых желез двенадцатипенстной кишки, высоту мукоцитов подслизистых желез, диаметр их ядер, ядерно-цитоплазматические отношения у них, относительный объем их повреждений. Количественные показатели обрабатывали статистически.

Результаты исследований и их обсуждение. Результаты анализа полученных данных установлили, что через месяц после резекции 31,5 \% паренхимы печени большинство структур подслизистых желез двенадцатиперстной кишки не изменялась. Относительный объем поврежденных мукоцитов подслизистых желез двенадцатиперстной кишки при этом статистически достоверно (p<0,001) вырос в 1,5 раза. В опытных животных при удалении 58,1\% паренхимы печени при вскрытии брюшинной полости наблюдалось расширение печеночной воротной вены, полнокровие и расширение брыжеечных вен и видимого венозного русла тонкой и толстой кишок, асцит, спленомегалия, что подтверждало наличие пострезекционной портальной гипертензии. Через месяц после резекции 58,1 \% паренхимы печени исследуемые морфометрические параметры существенно изменялись. Так, диаметр подслизистых желез двенадцатиперстной кишки статистически достоверно ( $<<0,001)$ увеличился на 25,9 \%. Высота мукоцитов подслизистых желез двенадцатиперстной кишки в данных экспериментальных условиях с высокой степенью достоверного различия ( $<0,001)$ уменьшилась на 12,1 \% по сравнению с аналогичным контрольным количественным морфологическим показателем, а диаметр их ядер - на 7,3\%. Неравномерные диспропорциональные изменения пространственных характеристик ядра и цитоплазмы мукоцитов приводили к выраженным нарушениям ядерно-цитоплазматических отношений в этих клетках. При этом указанный морфометрический параметр статистически достоверно $($ р $<0,01)$ увеличился на $11,1 \%$. Выявленные изменения ядерно-цитоплазматических отношений свидетельствовали о нарущении структурного клеточного гомеостаза. Относительный объем поврежденных мукоцитов подслизистых желез двенадцатиперстной кишки через месяц после удаления 58,1 \% паренхимы печени с выраженной статистически достоверной разницей (p<0,001) вырос в 9,7 раза.

Выводы. Резекция больших объемов паренхимы печени приводит к пострезекционной портальной гипертензии и выраженной структурной перестройке подслизистых желез дванадцятиперстной кишки, которая подтверждалась изменениями их топографрии, нарушением клеточного структурного гомеостаза мукоцитов и значительным увеличением относительного объема их повреждений, инфильтративными и склеротическими процессами, что существенно ухудшает функциональную морфологию желез и усиливает диссункцию исследуемого органа.

ключевые слова: резекция печени; подслизистые железы дванадцятиперстной кишки; мукоциты; морфометрия. 